\title{
Elaboration of a cereal bar enhanced with flour of buriti pulp (Mauritia flexuosa $L$.
}

\section{Elaboração de barra de cereal enriquecida com farinha da polpa de buriti (Mauritia flexuosa L.)}

Ila Raquel Mello Cardoso ${ }^{1, *}(\mathbb{D}$, Abraham Damian Giraldo Zuniga1,(i), Pãmella Fronza1,(D), Amanda Galvão Maciel $^{1,(\mathbb{D})}$ e Jéssica da Silva Ferreira ${ }^{1,(\mathbb{D})}$

1 Universidade Federal do Tocantins. Campus Universitário de Palmas, Av. Ns 15 Quadra 109 Norte Alcno 14, s/n - Plano Diretor Norte CEP 77015-016. Palmas-TO, Brasil.

*Corresponding author: ilarakel@hotmail.com

\section{ABSTRACT}

OPPEN ACESS

\section{Additional information}

Received: 01/20/2017

Accept: 03/11/2017

Published: 07/08/2017

Editor:

Neila Mello S. Cortez Universidade Federal de Pernambuco, PE.

neilacortez@yahoo.com.br

Ethic Committee for Research with Human Beings, Tocantins Federal University, process number 006/2014.

\section{Double blind reviews}

Reviews process

Prot. 1372017R02 (Brazil)

Prot. 1372017R03 (Brazil)

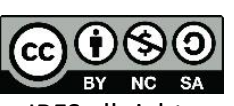

JBFS all rights

Copyright: (C) 2017
The buriti (Mauritia flexuosa L) shows high percentage of sugar, proteins, and carotenoids among others. The developing of the cereal bar added with dehydrated fruit has become a very important activity due its popularity, practicality, nutritional value and sensory characteristics. This work had as a goal, elaborate a cereal bar enhanced with different concentrations of $10 \%, 20 \%$ and $30 \%$ buriti flour. About the buriti pulp physical and chemical composition, were found $60.33 \%$ of moisture, $3.69 \%$ of protein, $49.8 \%$ of lipids, $0.18 \%$ of ashes, $46.64 \%$ of carbohydrates and $4.7 \mathrm{mg}$ of carotenoid $/ 100 \mathrm{~g}$ of buriti sample. About the cereal bar physical and chemical characterization, $12.4 \%$ of moisture, $11.96 \%$ of lipid percentage, $6.76 \%$ of protein percentage, $0.16 \%$ of ashes and $68.72 \%$ of carbohydrates percentage. As for the smell, the $30 \%$ flour sample revealed a significant difference from the $10 \%$ sample, but similarity with the $20 \%$ sample. About the buriti flavor, the $30 \%$ sample revealed a significant difference with the average of 8.1. This sample has shown bigger averages for the sensorial tonality, compression, cereal flavor, buriti flour smell and buriti flour flavor attributes, having a bigger rating of acceptability.

Keywords: Sensorial analysis. New product. Tasters training.

\section{RESUMO}

O buriti (Mauritia flexuosa L.) possui elevados teores de açúcares, proteínas e carotenoides. O desenvolvimento da barra de cereal adicionada de fruta desidratada tem se tornado uma atividade de elevada importância devido à popularidade, praticidade, valor nutricional e características sensoriais. O presente trabalho teve como objetivo elaborar uma barra de cereal enriquecida com diferentes concentrações de $10 \%, 20 \%$ e $30 \%$ de farinha de buriti. Quanto a composição química e física da polpa do buriti encontrou-se $60,33 \%$ de umidade, 3,69\% de proteína, $49,8 \%$ de lipídeos, $0,18 \%$ de cinzas, $46,64 \%$ de carboidratos e $4,7 \mathrm{mg}$ de carotenoide/100g de amostra do buriti. Quanto à caracterização física e química da barra de cereal, 12,4\% de umidade, $11,96 \%$ de teor lipídico, 6,76\% de o teor proteico e para cinzas de 0,16\% e teor de carboidrato de $68,72 \%$. Quanto ao odor, a amostra com $30 \%$ de farinha apresentou diferença significativa da amostra de $10 \%$, porém semelhança com de $20 \%$. Em relação ao sabor de buriti, a amostra de $30 \%$ apresentou diferença significativa com a média de 8,1 . Esta amostra apresentou maiores médias para os atributos sensoriais de tonalidade, compactação, aroma dos cereais, odor da farinha de buriti e sabor da farinha de buriti, tendo maior aceitabilidade.

Palavras-chaves: Análise sensorial. Novo produto. Treinamento de provadores. 


\section{INTODUCTION}

In Brazil, mainly in the northeast area, there is a huge diversity of exotic and native fruitful trees that are well adapted to the weather conditions, with a great economic potential for the internal and external commercialization of raw and industrialized fruits (HANSEN et al, 2008).

The buriti, a Mauritia flexuosa L. species fruit, shows high percentages of sugar, proteins, minerals, fatty acid, B complex vitamins and carotenoids (CARNEIRO; CARNEIRO, 2011).

The fruiting of buriti has its peak from December to June in the biggest part of Brazilian regions. In the micro region of Teresina-PI, Brazil, the fruiting occurs strongly between October and December, though in the state of Tocantins it starts in September. The production per tree varies from 2000 to 6000 fruits (LEAL, 2006).

The annual production in northeast and north region combined, is around 70 tons (fruit/harvest), although the characteristics of extraction and handmade production of its obtainment makes the offering seasonal. There is no information about agribusiness processing this good. Among the stimulus of the federal government we have a national program of school feeding (PNAE), which helps some co-ops and local farmers with the settling of micro agribusiness that show some interest for exploring the processed frozen pulp of buriti. The problems found in this activity are the extraction cost, low fruit yield (35\% of pulp at $60 \%$ moisture) and the lack of technology applied to this kind of processing (SAMPAIO, 2012).

The development of the cereal bar mixed with dehydrated fruit and cereal has become a high rated and important activity due the major popularity, practical, nutritional value and sensorial characteristics of this new product (SALATIR et al., 2011).

The buriti fruit is used for processing goods like pulp, sweet, jam, nectar, dyestuff, antioxidants and pulp flour, able to be introduced in the Brazilian feeding habit to prevent or minimize the occurring of some kinds of disease with a low cost, due a great production of this fruit with no availing (SANTOS et al., 2011).

The association between cereal bars and healthy food is a trend of the food industry, which improve the sales of these products. The growing concern for a healthy feeding that feeds and enhance health at the same time, put some food and ingredients at the preference top list of a growing number of Brazilian customers, like soy, soy lecithin, wheat germ and antioxidants (FREITAS, 2006).

The main characteristics analyzed in the creation of the cereal bar include the choosing of the cereal (oat, wheat, rice, barley, corn), the selection of the right carb to balance between flavor and durability, the nutritional enhancement, the process stability and the using of dietary fiber (GUTKOSKI et al.,2007). The cereal bars are developed from dehydrated fruit and cereal compaction, they have reached enormous popularity, due their great practicality, their nutritional value and the taste (SALATIR et al., 2011). This work had as an objective develop a cereal bar enhanced with different concentrations of $10 \%, 20 \%$ and $30 \%$ of buriti flour, analyzing the physical and chemical characteristics of the pulp and the cereal bar and the sensorial analysis of this nutritional product.

\section{MATERIAL AND METHODS}

The buriti fruits were harvested fresh and ripe, with uniform size and shape, in the city region of Palmas-TO, between September and December 2013. The samples were analyzed at the LAPSDEA lab (Food dehydration and bio molecular separation lab) at Tocantins Federal University - UFT. 


\section{Physical and chemical characterizing of the raw fruit}

The physical characterization analysis of the raw fruits were conducted through weight determination $(\mathrm{kg})$ using a semi analytical scale, longitudinal diameter $(\mathrm{mm})$ and transversal $(\mathrm{mm})$ with the help of a parking meter.

The buriti's raw fruit pulp was submitted to physical and chemical analysis: moisture level by straight drying in a heater at $105{ }^{\circ} \mathrm{C}$, protein by the Kjeldahl method, straight extraction of lipids in Soxhlet, ashes by the incineration of mineral residues in a muffle and carbohydrates by difference, according to IAL (2008). These were done in triplicates.

For the carotenoid determination, the following procedure was done: a $1 \times 10^{-2}$ $\mathrm{kg}$ sample was used for the extract, $3 \times 10^{-5} \mathrm{~mm}^{3}$ of isopropyl alcohol and $1 \times 10^{-5} \mathrm{~mm}^{3}$ of hexane. The mixture was homogenized, right after, $8,5 \times 10^{-5} \mathrm{~mm}^{3}$ water were added and transferred to the separation balloon. After a 30 minute rest, the sample was filtered and two more washings were done with $8,5 \times 10^{-5} \mathrm{~mm}^{3}$ of distilled water. Later, the mixture was filtered and placed in a $5 \times 10^{-5} \mathrm{~mm}^{3}$ volumetric flask containing $5 \times 10^{-6}$ $\mathrm{mm}^{3}$ of acetone, checking the volume with hexane. The reading was done, in triplicate, of this extract in a spectrophotometer, using a $5 \times 10^{-5} \mathrm{~mm}^{3}$ volumetric flask made solution as white, with $5 \times 10^{-6} \mathrm{~mm}^{3}$ of acetone, tested with hexane.

\section{Dehydration of the buriti's fruit pulp}

The following steps of buriti processing were done: reception, selection, washing, preparation, pulping, pulp molding, dehydration and storage.

The fruits were selected, washed and sanitized in chlorinated water $(5 \mathrm{ppm})$ during 180 s and, after that, washed with distilled water to remove the chlorine residues.

The raw fruits were subjected to a cooking process during $1080 \mathrm{~s}$ at $100 \cong \mathrm{C}$, and after that, pulped, separating the fruit in 4 parts: peel, pulp, fiber and seed (SANTOS et al., 2011). The pulps were frozen in a conventional freezer in portions of $0.5 \mathrm{~kg}$ approximately, being unfrozen under refrigeration only in the day of the pulp dehydration.

The dehydration of the fruit pulp were done in a stainless steel tray dehydrator with hot air circulation until it reached a moisture percentage around $8 \%$, given that the drying temperature didn't exceed 338.15-343.15K for approximately $2160 \mathrm{~s}$ (SILVA, SANTOS, COSTA, 2016).

The dry stuff was grinded in a multiprocessor and sifted later, packaged and stored at an ambient temperature of approximately $303.15 \mathrm{~K}$ until the moment of the product elaboration.

Three cereal bars with different concentration of buriti flour, were elaborated. The table 1 shows the different formulations for this foodstuff.

After the homogenization of the dry ingredients and the heated assemblage syrup, it was stored under refrigeration for $360 \mathrm{~s}$.

\section{Elaboration of the cereal bar enhanced with buriti's pulp flour}

From buriti's pulp flour characterization analysis, 3 (three) different cereal bars were formulated using different concentrations of this flour.

Feedstock used for the formulation:

- Liquid ingredients as the assemblage syrup (corn syrup and agave gravy);

- Dry ingredients as cereals (coarse rice flakes, oat and linseed) and the buriti's pulp flour.

The processing steps were composed of: weighing the dry ingredients, assemblage syrup cooking until it reached $338.15 \mathrm{~K}$, mass formation, heated 
assemblage syrup and dry ingredients homogenization, placing of the cereal bar under refrigeration for $360 \mathrm{~s}$, cutting of the cereal bar with approximately $0.01 \mathrm{~m}$ thickness, slicing and standardization of the cereal bar, storage in proper packages, in a PET/PEBD/AL/PEBD film.

Table 1. Formulations of cereal bars enriched with buriti flour

\begin{tabular}{ccccccc}
\hline Formulation & $\begin{array}{c}\text { Buriti } \\
\text { flour (\%) }\end{array}$ & $\begin{array}{c}\text { Brownrice } \\
\text { flakes (\%) }\end{array}$ & $\begin{array}{c}\text { Oatmeal } \\
(\%)\end{array}$ & $\begin{array}{c}\text { Linseed } \\
(\%)\end{array}$ & $\begin{array}{c}\text { Glucose } \\
\text { Corn (\%) }\end{array}$ & $\begin{array}{c}\text { Agave } \\
\text { syrup (\%) }\end{array}$ \\
\hline Formulation 01 & 30 & 30 & 20 & 20 & 70 & 20 \\
Formulation 02 & 20 & 40 & 20 & 20 & 70 & 20 \\
Formulation 03 & 10 & 50 & 20 & 20 & 70 & 20 \\
\hline
\end{tabular}

\section{Physical and chemical characterization of the cereal bar enhanced with buriti flour}

The samples of cereal bar were subjected to the following physical and chemical analysis: moisture percentage through direct drying in a heater at $378.15 \mathrm{~K}$, protein through the Kjeldahl method, lipids through direct extraction in Soxhlet, ashes through mineral residue incineration and carbohydrates by difference, according to IAL (2008). All of them done in triplicates.

\section{Sensorial Analysis}

This development research of the cereal bar enhanced with buriti flour was approved by the Ethic Committee for Research with Human Beings, Tocantins Federal University, process number 006/2014.

At the interview time, the tasters were warned about the predictable risks of food sensory analysis such as intoxications, infections or even poisoning, allergies or intolerance to some of the products. The tasters were warned about the substances or ingredients that could cause allergic reactions or health harm, such as sugar and gluten. So the participation of people with diabetes and people with celiac disease wasn't allowed and when these health problems were identified, the ones who fit were excluded from the training.

The tasters' training was conducted like this:

a) Interview: the candidate's health condition was analyzed, watching for the allergies or intolerance (disqualified if fit), the dental condition, the capability to taste the product, the intellectual curiosity and the seriousness to participate the research. At this level, the tasters who showed any of these problems were dismissed.

b) Smell recognizing test: 16 different kinds of smell were given to a nominal identification through a Smell Identification Test. The participants had to identify at least $70 \%$ of the smells. The smells used were orange juice, bell pepper, milk, pepper, chocolate milk, onion, oregano, spearmint, mint, cinnamon, tomato sauce, rosemary, vanilla, chamomile, vinegar and clove. At this point, only the tasters who scored $70 \%$ of the smells continued the test.

c) Taste identification test: identified taste solutions with the basic tastes were given, such as: sweet, salted, acid and bitter. The participants received 4 samples and filled the taste recognizing form. In order to continue the test, they had to hit $100 \%$ score. For the inclusion, the tasters had to identify all the tastes given with the samples, those who didn't prang the totality, were dismissed. 
d) Difference test applied to the product: at this point, the licensed judge analyzed the differences of the presented product. The judgers analyzed the product sensory, discussing in group the weighing of the recognized characteristics. At this point, all the tasters approved early, were able to identify the differences between the cereal bars enhanced with buriti flour.

The sensory analysis was conducted with 10 trained and licensed tasters, from different gender and ages. The tasters received the sample with of enhanced cereal bar with three different concentrations of buriti flour, numbered previously with three digits, a glass of water that was used as cleaner and an evaluation sheet. In this sheet the following sensory attributes were evaluated: look (color and compaction), smell (cereal and fruity), texture (succulence) and taste (cereal, sweetish, dehydrated fruit). The attributes were set varying from indistinguishable to very intense with a non structured hedonic scale of $0.09 \mathrm{~m}$. Were also evaluated the buying intensity of the samples, using a 5 points scale, being 1 - surely would buy, 2- probably would buy, 3not sure if would buy or not, 4- probably wouldn't buy and 5- certainly wouldn't buy.

Through the Quantitative Describing Analysis (QDA), the appearance related significance level is evaluated, concerning the buriti flour concentration e the cereal grains amount (as oat and linseed), uniformity of these ingredients, the kind of sugar used (caramelization). As it comes to the smell, the characteristic buriti flour smell and the cereal smell were analyzed. The noticed taste came from the buriti sweetness with the corn syrup and the agave gravy, along with the taste of the rice flakes, oat and linseed. About the sound, the crunchiness was evaluated (sound intensity when chewing) due rice flakes, linseed and oat. The texture related to the hardness and the necessary strength to break the ingredients of the cereal bar.

\section{RESULTS}

\section{Physical and chemical characterization of the raw fruit}

The buriti fruits obtained in the city of Palmas - TO had the following physical measurement: average weight of $0.0463 \mathrm{~kg}$, average longitudinal diameter of $0.032 \mathrm{~m}$, average transversal of $0.045 \mathrm{~m}$ and the pulp yield of $9.2 \%$. Concerning the amount of carotenoid, the result found was $4.7 \times 10^{-6} \mathrm{~kg} / 10^{-4} \mathrm{~kg}$ of buriti sample.

\section{Chemical and physical characterization of the cereal bar enhanced with buriti flour}

Were found in the chemical and physical characterization of the cereal bar, $12.4 \%$ of moisture, $11.96 \%$ of lipid percentage, $6.76 \%$ of protein percentage, $0.16 \%$ for ashes and $68.72 \%$ of carbohydrate percentage.

\section{Sensory analysis}

At the interview point 11 (eleven) tasters were oriented, being all of them qualified for showing commitment to the research, just 1 (one) didn't know the fruit and all of them were aware of the risks of allergy and intolerance. The smell recognizing test disqualified only one taster because he didn't recognize at least $70 \%$ of the smells given.

All of the 10 (ten) tasters were approved on the taste identification and participated of the Quantitative Describing Analysis (QDA).

The 10 (ten) qualified tasters received a sample of the cereal bar enhanced with 3 (three) different concentrations of buriti flour. This way was conducted the evaluation test for these cereal bars and elaborated the sensory profile of this product. 
Table 2 shows the average results found on the cereal bar enhanced with buriti flour sensory analysis at $10 \%, 20 \%$ and $30 \%$.

Table 2. Sensory evaluation of cereal bar enriched with $10 \%, 20 \%$ and $30 \%$ of flour buriti.

\begin{tabular}{cccc}
\hline Attribute & $10 \%$ & $20 \%$ & $30 \%$ \\
\hline Tonality & $4.2^{\mathrm{a}}$ & $4.5^{\mathrm{a}}$ & $6.6^{\mathrm{a}}$ \\
Compression & $4.6^{\mathrm{a}}$ & $4.8^{\mathrm{a}}$ & $6.8^{\mathrm{a}}$ \\
Grains aroma & $3.2^{\mathrm{a}}$ & $3.5^{\mathrm{a}}$ & $3.6^{\mathrm{a}}$ \\
Buriti odor of flour & $3.5^{\mathrm{a}}$ & $4^{\mathrm{ab}}$ & $6.7^{\mathrm{b}}$ \\
Crunchiness & $6.7^{\mathrm{a}}$ & $6.3^{\mathrm{a}}$ & $5.2^{\mathrm{a}}$ \\
Cereal taste & $6.6^{\mathrm{a}}$ & $5.7^{\mathrm{a}}$ & $4.1^{\mathrm{a}}$ \\
Honey & $5.8^{\mathrm{a}}$ & $4.8^{\mathrm{a}}$ & $5.7^{\mathrm{a}}$ \\
Buriti taste of flour & $4.4^{\mathrm{a}}$ & $5^{\mathrm{a}}$ & $8.1^{\mathrm{b}}$ \\
\hline
\end{tabular}

\section{DISCUSSION}

The pulp yield is inferior when compared with Carneiro and Carneiro (2001), which has shown an output of $10.98 \pm 1.14 \%$. When analyzing the chemical composition of the buriti pulp was found $60.33 \%$ of moisture and $3.69 \%$ of protein.

When analyzing the chemical composition of buriti pulp was found the protein value upper to the study conducted by Carneiro and Carneiro (2011) that obtained $1.3 \%$, there were obtained $51.67 \%, 1.54 \%$ and $31.24 \%$ for lipids, ashes and carbohydrates, respectively. In this actual work were found a similar result of $49.8 \%$ for lipids, lower values of $0.18 \%$ for ashes and higher values of $46.64 \%$ for carbohydrates.

Although, the amount of carotenoids was inferior to the one found by Sousa et al. (2010) that showed $7.7810^{-6} \mathrm{~kg} / 10^{-4} \mathrm{~kg}$.

To the cereal bar mixed with murici-raisin fruit, there were seen approximately $10 \%, 4.7 \%, 7.3 \%, 1.2 \%$ and $76 \%$ for moisture, lipids, protein, ashes and carbohydrates, respectively, lower values for moisture, lipids and protein of the cereal bar enhanced with buriti flour, but the ashes and carbohydrates values were higher (GUIMARÃES; SILVA, 2009).

The tonality, compacting, cereal aroma, crunchiness, cereal flavor and sweetness attributes when compared to the 3 (three) other formulations, didn't show significant differences. The compacting of this product was related to the hygroscopic function of the buriti flour, an adjective that is presented in dehydrated food which affects the consistency of the product according to the moisture absorbance (REIS et al., 2012).

According to Sampaio, Ferreira and Canniatti-brazaca (2009), the cereal bar samples enhanced with iron showed average levels for cereal aroma between 5.42 and 5.78, comparing with this actual work it is possible to see that this attribute was between 3.2 and $3.6 \%$, being a lower value due the concentration of buriti flour and the characteristic aroma of this fruit.

When evaluating the buriti flour smell, it's possible to see that the sample with $30 \%$ of flour showed a significant difference from the $10 \%$ sample, but is similar to the $20 \%$ sample. This buriti flour attribute, in all the samples, had a bigger perception when related to the cereal aroma.

The evaluated parameter of the crunchiness had a higher value for the $10 \%$ buriti flour enhanced cereal bar, since this formulation showed a higher concentration of rice flakes. 
According to Sampaio, Ferreira and Canniatti-brazaca (2009), in the cereal bar enhanced with iron formulation, it's observed that the average values of the sweet taste were between 6.28 to 7.06 , due the using of chocolate cover, corn syrup and brown sugar. The sweetness level of food is determined by the composition of several types of sugar. The corn syrup is made of $17 \%$ glucose, $2 \%$ fructose, $2.8 \%$ saccharose and $8.7 \%$ maltose, being considered low sweetness. The sweetness isn't calculated by absolute terms, is a resulting value of the degustation panel, so when compared to the sweetness level of saccharose we have 60 and 100, sweetness level that is relative to glucose syrup and saccharose, respectively (GUTKOSKI et al., 2007).The cereal bar enhanced with buriti flour sweetness for the different concentrations varied from 4.8 to 5.8, being lower to the found on the iron enhanced cereal bar (SAMPAIO; FERREIRA; CANNIATTI-BRAZACA, 2009), due this inferior characteristic included agave gravy in the formulation, composed by a high percentage of fructose with a sweetness level 1.3 times higher than the saccharose, the sweetness level of fructose compared to saccharose is 173 (GUTKOSKI et al., 2007).

The higher average grade for the evaluated attributes was the one of the buriti flavor taste of 8.1 for the $30 \%$ sample, showing a significant difference compared to the other samples.

Was noticed that the cereal bar enhanced with $30 \%$ of buriti flour, presented average values higher than the others for the following attributes: tonality, compacting, cereal aroma, buriti flour smell and buriti flour flavor. Similar result to the one found by Santos et al. (2011), because in the elaboration of the cookie enhanced with the buriti flour with vitamin a source, the quantitative description analysis showed a higher orange coloration (carotenoid presence), stronger buriti aromas and a stronger fruity taste due the increasing of flour concentration in this cookie.

When evaluated the buying intensity, $80 \%$ of the tasters told that would certainly buy the samples enhanced with $30 \%$ of buriti flour, and the other $20 \%$ said they would probably buy. The $20 \%$ buriti flour samples would probably be bought by $80 \%$ of the tasters, one said that would surely buy and the other was doubtful about it. The $10 \%$ sample showed $90 \%$ and $10 \%$ of buying intensity for probably buying and doubt about buying. When compared the results above with the ones obtained by the cashew cereal bar study, was observed that $74 \%$ would certainly buy and $26 \%$ maybe would buy (OLIVEIRA et al., 2013).

\section{CONCLUSIONS}

Through sensory analysis done with cereal bars enhanced with buriti flour, the $30 \%$ buriti flour concentration sample showed high averages for the sensory tonality attributes, compacting, cereal aroma, buriti flour smell and buriti flour flavor, with a bigger acceptance.

\section{AUTHOR CONTRIBUITION}

Ila Raquel Mello Cardoso participate in the conduction of the experiment and developed the article. Professor Abraham Zuniga project leader. Pãmella Fronza, Amanda Galvão and Jessica da Silva Ferreira participate in the conduction of the experiment.

\section{COMPETING INTERESTS}

The authors declare there are no competing interests. 
FUNDING

The authors no received funding this work.

\section{ETHIC COMMITEE}

This development research of the cereal bar enhanced with buriti flour was approved by the Ethic Committee for Research with Human Beings, Tocantins Federal University, process number 006/2014.

\section{REFERENCES}

CARNEIRO, TB.; CARNEIRO, JGM. Frutos e polpa desidratada buriti (Mauritia flexuosa L.): aspectos físicos, químicos e tecnológicos. Revista Verde, v.6, n.2, p. 105-111, 2011.

FREITAS, D.G.C. et al. Caracterização e avaliação sensorial de barra de cereais funcional de alto teor protéico e vitamínico. Ciência e Tecnologia de Alimentos, v. 26, n.2, p. 318-324, 2006. DOI: 10.1590/S010120612006000200014.

GUIMARÃES, MM.; SILVA, MS. Qualidade nutricional e aceitabilidade de barras de cereais adicionadas de frutos de murici-passa. Revista Instituto Adolfo Lutz, v.68, n.3, p.426-433, 2009.

GUTKOSKI, LC. et al. Desenvolvimento de barras de cereais à base de aveia com alto teor de fibra alimentar. Ciência e Tecnologia de Alimentos, v.27, n.2, p. 355-363, 2007. DOI: 10.1590/S0101-20612007000200025.

HANSEN, DS. et al. Caracterização química de frutos de jenipapeiros nativos do Recôncavo Baiano visando ao consumo natural e industrialização. Revista Brasileira de Fruticultura, v.30, n.4, p. 964-969. 2008. DOI: 10.1590/S0100-29452008000400021.

LEAL, AF. Condições do extrativismo e aproveitamento das frutas nativas da microrregião de Teresina - Piauí. Revista Ceres, v.53, n.310, p.511-513, 2006.

OLIVEIRA, CFP. et al. Desenvolvimento, avaliação sensorial e físico-química de barra de cereal de caju. Revista Brasileira de Tecnologia Agroindustrial, v.7, n.1, p.1-9, 2013. DOI:10.3895/S198136862013000100006.

REIS, RC.et al. Obtenção da farinha de bocaiuva (Acrocomia aculeata (Jacq.) Lodd. ex Mart) na Casa do Artesão de Corumbá-MS. Cadernos de Agroecologia, v.7, n.2, p.1-6, 2012.

SALATIR, RJ. et al. Desenvolvimento de barra de cereal salgada enriquecida com farinha de albedo de maracujá. Enciclopédia Biosfera, v.7, n.12, p.1-7,2011.

SAMPAIO, C. R. P.; FERREIRA, S. M. R.; CANNIATTI-BRAZACA, S. G. Perfil sensorial e aceitabilidade de barras de cereais fortificadas com ferro. Alimentos e Nutrição, v.20, n.1, p.95-106, 2009.

SAMPAIO, M. B. Manual Tecnológico de Aproveitamento Integral do Fruto e da Folha do Buriti (Mauritia flexuosa). Brasília: Instituto Sociedade, População e Natureza (ISPN), p.80 2012.

SANTOS, CA.; et al. Elaboração de biscoito de farinha de buriti (Mauritia flexuosa L. f.) com e sem adição de aveia (Avena sativa L.). Revista Brasileira de Tecnologia Agroindustrial, v. 5, n. 1, p. 262-273, 2011. DOI:10.3895/S1981-36862011000100002.

SILVA, CEN; SANTOS, VAQ; COSTA, DPS. Produção e avaliação sensorial de barras de cereais a base de farinha de banana verde. Revista do Agronegócio, v.5, n. esp., p.1-12, 2016. 